\title{
Analisis Resistensi Spermatozoa Sapi Bali Terhadap Keberhasilan Inseminasi Buatan di Kabupaten Tebo
}

\author{
Fachroerrozi Hoesni*, Firmansyah, Farizal, Fauzan \\ Fakultas Peternakan Universitas Jambi \\ *Correspondence email: rozi.hoesni@gmail.com
}

\begin{abstract}
The purpose of this study is to find out the difference in the success rate of Artificial Insemination of Balinese cattle in Rimbo Bujang Subdistrict, Rimbo Ilir, and to know the influence of spermatozoa resistance and spermatozoa abnormality on the success of Artificial Insemination in Balinese cattle. The method used is the survey method, while the sample withdrawal technique is used clustering. Data analysis uses multiple linear regressions. The results showed that the success of Artificial Insemination based on Service per Conception (S/C) showed the number 1.56 means the success of IB is good, while judging from the calving interval (CI) value in cattle which is 12.9 months, it means it is ideal. It can be concluded that the success of Artificial Insemination (IB) is good, while motility is the success of Artificial Insemination (IB), as well as the percentage of life and spermatozoa abnormalities does not affect the success of Artificial Insemination (IB) in Balinese cows.
\end{abstract}

Keywords: Service per Conception; Calving Interval; Spermatozoa

\section{PENDAHULUAN}

Inseminasi Buatan (IB) diterapkan di Indonesia sejak tahun 1953 pada ternak sapi perah, kemudian pada sapi potong, kerbau dan hasilnya sampai saat sekarang ini telah dirasakan masyarakat, ditandai dengan tingginya harga jual dari ternak hasil tersebut, namun demikian pelaksanaan di lapangan belum optimal sehingga hasilnya (tingkat kelahiran) dari tahun ke tahun berfluktuasi. Tingkat kelahiran hasil IB pada sapi potong dan kerbau berfluktuasi setiap tahunnya. Pelaksanaan kegiatan Inseminasi Buatan (IB) merupakan salah satu upaya penerapan teknologi tepat guna yang merupakan pilihan utama untuk peningkatan populasi dan mutu genetik ternak. Melalui kegiatan tersebut penyebaran bibit unggul ternak sapi dapat dilakukan dengan murah, mudah dan cepat, serta diharapkan dapat meningkatkan pendapatan peternak. Salah satu permasalahan yang dihadapi oleh peternak sapi secara ekstensif adalah produktivitas ternak sapi yang rendah. Di Provinsi Jambi sapi bali sudah banyak diternakkan. Pada tahun 2013 populasi sapi di Provinsi Jambi sebanyak 118.985 ekor (Badan Pusat Statistik, 2010) setelah tahun tersebut populasi sapi terus mengalami kenaikan walupun hanya sekitar $0,06 \%$ per tahun, dan pada tahun 2017 populasi bali sebanyak 156.501 ekor (Badan Pusat Statistik, 2010) Di Provinsi Jambi pada tahun 2016 populasi sapi sebanyak 153.220 ekor sementara di Kabupaten Tebo pada Tahun 2016 populasi sapi sebanyak 18.690 ekor. Kabupaten Tebo menduduki peringkat ketiga populasi sapi terbanyak setelah Kabupaten Bungo dan Kabupaten Muaro Jambi. Berdasarkan hasil evaluasi Kementerian Pertanian Republik Indonesia tentang pelaksanaan Inseminasi buatan (IB) sampai saat ini masih belum sesuai dengan harapan. Hal ini terkait dengan masih adanya berbagai kendala dan permasalahan teknis yang perlu ditangani bersama. Keberhasilan pelaksanaan IB pada ternak sapi telah mencapai 2.116 .159 akseptor dengan kelahiran 1.333.075 ekor. Keberhasilan pelaksanaan IB ternak sapi di dataran sedang yaitu Kabupaten Tebo menurut Laporan Dinas Peternakan tahun 2016 berbeda-beda (target dan realisasi). Keberhasilan ditentukan beberapa faktor, diantaraya kualitas semen yang digunakan. Faktor yang mempunyai pengaruh terhadap kualitas semen adalah bangsa sapi pejantan. Semen hasil penampungan di amatii secara makroskopis meliputi volume, warna, bau, $\mathrm{pH}$, kekentalan serta untuk mikroskopis pemeriksaan meliputi motilitas, gerakan massa, konsentrasi, persentase hidup, abnormalitas spermatozoa.

Motilitas spermatozoa dapat diamati berdasarkan persentase sperma yang motil atau mempunyai pergerakan yang progresif, dan dijadikan pedoman pada penilaian semen untuk inseminasi,dimana.motilitas sperma mempunyai korelasi yang tinggi dengan fertilitas untuk pembuahan (Hunter, 1992 dan Toelihere, 1993). Lebih lanjut dinyatakan Hunter (1992) semen yang berkualitas baik adalah memiliki sperma hidup yang bergerak maju ke depan atau motil progresif dalam jumlah banyak.

Persentase sperma dipengaruhi oleh suhu, sinar matahari langsung, kejut dingin dan goncangan yang berlebihan, Toelihere (1993). Hafez (1993) persentase hidup spermatozoa diatas $60 \%$. hal tersebut sejalan pernyataan Frandson (1993) bahwa selama persentase hidup spermatozoa belum mencapai $30 \%$, maka semen tersebut masih layak digunakan untuk inseminasi. Dipertegas Toelihere (1993) yang menyatakan bahwa standar persentase hidup sperma semen beku adalah $50 \%$.

Keberhasilan Inseminasi Buatan (IB) di Kabupaten Tebo terlihat dari indikator teknis masih belum memuaskan, disamping itu kondisi sosial peternak dan petugas atau inseminator juga perlu diperhatikan untuk mencapai keberhasilan tersebut. 
Tujuan dari penelitian ini adalah mengetahui perbedaan tingkat keberhasilan IB ternak sapi Bali antara Kecamatan Rimbo Bujang, Rimbo ulu, Rimbo ilir dan untuk mengetahui pengaruh resistensi spermatozoa terhadap keberhasilan IB pada ternak sapi Bali di Kabupaten Tebo.

\section{Metode}

Metode yang digunakan pada penelitian ini adalah metode survei, metode survei (survey method) yaitu metode pengamatan atau penyelidikan yang kritis untuk mendapatan keterangan yang sebenarnya dan baik terhadap suatu persoalan tertentu dan di dalam suatu daerah. Teknik survei ini mengambil sampel dari suatu populasi dan menggunakan kuesioner sebagai alat pengumpulan data dengan maksud menjelaskan hubungan kausal antara variabel-variabel (Singarimbun dan Effendi, 1984). Data Primer diperoleh dari penilaian motilitas, persentase hidup, abnormalitas spermatozoa serta tingkat keberhasilan IB. Sedangkan data sekunder diperoleh dari Badan Pusat Statistika Kabupaten Tebo tahun 2016-2017, Dinas Peternakan Kabupaten Tebo. Teknik penarikan sampel yang digunakan pada penelitian ini adalah clustering (pengelompokan). Menurut Tan (2006) clustering adalah sebuah proses untuk mengelompokkan data ke dalam beberapa cluster atau kelompok sehingga data dalam satu cluster maksimum dan data antar cluster memiliki kemiripan yang minimum.Pada penelitian ini Cluster I adalah semen (straw) yang dipakai oleh inseminator untuk sapi yang di IB di Kecamatan Rimbo Bujang. Cluster II adalahsemen (straw) yang dipakai oleh inseminator untuk sapi yang diIB di Kecamatan Rimbo Ulu. Cluster III adalah semen (straw) sapi yang dipakai oleh inseminator untuk sapi yang di IB di Kecamatan Rimbo Ilir.

Analisis regresi merupakan salah satu teknik analisis data dalam statistika yang seringkali digunakan untuk mengkaji hubungan antara beberapa variabel dan meramal suatu variabel (Kutner et al, 2004).

Model matematis yang digunakan adalah:

$\mathrm{Y}=\mathrm{a}+\mathrm{b}_{1} \mathrm{X}_{1}+\mathrm{b}_{2} \mathrm{X}_{2}+\mathrm{b}_{3} \mathrm{X}_{3}+\mathrm{e}$

Keterangan: $\mathrm{Y}=$ Tingkat Keberhasilan Inseminasi Buatan (IB); $\mathrm{X}_{1}=$ Motilitas Sperma, $\mathrm{X}_{2}=$ Persentase Hidup Sperma, $\mathrm{X}_{3}=$ Abnormalitas Sperma, $\mathrm{a}=$ Konstanta atau intersep, $b_{1} b_{3}=$ Koefisien regresi masing-masing variabel, $\mathrm{e}=$ Error, $\mathrm{I}=1,2,3$.

\section{$U j i-F$}

Uji F bertujuan untuk menguji pengaruh bersamasama (silmutan), melihat keterkaitan variabel bebas secara bersama-sama dalam mempengaruhi variabel terikat.

1. $\mathrm{H}_{0}=\mathrm{X}_{1}, \mathrm{X}_{2}, \mathrm{X}_{3}=0$, berartikanmotilitas, persentase hidup,abnormalitas spermapada semen sapi bali secara simultan tidak berpengaruh terhadap
Keberhasilan Inseminasi Buatan pada sapi Bali di Kabupaten Tebo.

2. $\mathrm{H}_{\mathrm{a}}=\mathrm{X}_{1}, \mathrm{X}_{2}, \mathrm{X}_{3}=0$, berartikanmotilitas, persentase hidup,abnormalitas sperma pada semen sapi balisecara simultan berpengaruh terhadap Keberhasilan Inseminasi Buatan pada sapi Bali di Kabupaten Tebo.

Untuk menguji signifikasi atau adanya pengaruh hipotesis alternatif dilakukan uji $\mathrm{F}$ menurut Sugiyono (2011), dengan rumusan sebagai berikut:

$\mathrm{F}=\frac{R^{2} / \mathrm{k}}{\left(1-R^{2}\right) /(n-k-1)}$

Keterangan: R : Koefisien korelasi ganda, K : Jumlah variabel independen, $\mathrm{N}$ : Jumlah anggota sample.

Setelah menghitung uji $\mathrm{F}$ maka hasil dari uji $\mathrm{F}$

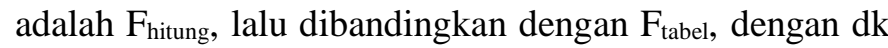
$($ degree of freedom $)$ pembilang $=\mathrm{k}$ dan $\mathrm{dk}$ penyebut $=$ (n-k-1), dengan taraf kesalahan yang ditetapkan misalnya $5 \%=0,05$. Jika $\mathrm{F}_{\text {hitung }}<\mathrm{F}_{\text {tabel }}$, maka $\mathrm{H}_{0}$ diterima $\left(\mathrm{H}_{\mathrm{a}}\right.$ ditolak $)$, dan jika $\mathrm{F}_{\text {hitung }}>\mathrm{F}_{\text {tabel, }}$ maka $\mathrm{H}_{0}$ ditolak $\left(\mathrm{H}_{\mathrm{a}}\right.$ diterima).

\section{Uji - $t$}

Pengujian ini dilakukan untuk mengetahui signifikasi atau tidak signifikan dari pengaruh variabel independen terhadap variabel dependen secara parsial (sendiri-sendiri).

1. $\mathrm{H}_{0}=\mathrm{X}_{1}, \mathrm{X}_{2}, \mathrm{X}_{3}=0$, berartikan motilitas, persentase hidup,abnormalitas sperma pada semen sapi bali secara parsial tidak berpengaruh terhadap Keberhasilan Inseminasi Buatan pada sapi Bali di Kabupaten Tebo.

2. $\mathrm{H}_{\mathrm{a}}=\mathrm{X}_{1}, \mathrm{X}_{2}, \mathrm{X}_{3}=0$, berartikan motilitas, persentase hidup,abnormalitas sperma pada semen sapi bali secara parsial berpengaruh terhadap Tingkat Keberhasilan Inseminasi Buatan pada sapi Bali di Kabupaten Tebo.

Untuk menguji hipotesis secara parsial, digunakan rumus statistic uji t (Sugiyono, 2011), sebagai berikut:

$\mathrm{t}=\frac{r \sqrt{n-2}}{\sqrt{1-r}}$

Keterangan: T : Hasil uji tingkat signifikasi; R : Korelasi persial yang ditemukan; $\mathrm{N}$ : Jumlah data

\section{HASIL DAN PEMBAHASAN}

Kabupaten Tebo terdiri dari 12 Kecamatan dan $112 \mathrm{desa} /$ kelurahan, terdiri dari 107 desa dan 5 kelurahan yaitu Kelurahan Muara Tebo, Tebing Tinggi, Wirotho Agung, Sungai Bengkal, dan Pulau Temiang. Sektor menyerap tenaga kerja terbesar di Kabupaten Tebo adalah sektor pertanian, Perkebunan, Kehutanan, dan Perikanan. Komoditi peternakan yang banyak 
berkembang di Kabupaten Tebo adalah ternak sapi, kerbau, domba, ayam dan itik. Peternakan yang ada di Kabupaten Tebo ada yang menggunakan modalnya sendiri untuk menjalankan usaha ternak danada juga menerima bantuan ternak dari pemerintah.

Kabupaten Tebo merupakan kabupaten yang memiliki tingkat populasi ternak sapi ke-3 terbesar di Provinsi Jambi setelah Kabupaten Bungo dan Kabupaten Muaro Jambi. Peningkatan ternak sapi di kabupaten Tebo dalam waktu 5 tahun terakhir mengalami pertumbuhan sebesar $8,95 \%$. Pertumbuhan tertinggi dalam waktu 5 tahun terakhir ini terjadi pada tahun 2017 dengan pertumbuhan sebesar $8,08 \%$. Populasi ternak sapi di Kabupaten Tebo mengalami fluktuasi setiap tahunnya.

\section{Faktor Keberhasilan Inseminasi Buatan Service per Conception (S/C)}

Service per Conception (S/C) adalah angka yang menunjukkan berapa kali perkawinan atau inseminasi buatan yang dibutuhkan oleh ternak sampai menghasilkan kebuntingan. Ternak yang kondisi tubuhnya sangat kurus memiliki cadangan lemak yang kurang, sehingga mengakibatkan rendahnya tingkat reproduksi sapi.

Tabel 1. Service Per Conception (S/C)

\begin{tabular}{|c|c|c|c|}
\hline No & Kecamatan & $\mathrm{N}$ & $\mathrm{S} / \mathrm{C}$ \\
\hline 1 & Rimbo Ilir & 12 & $1,50 \pm 0,43$ \\
\hline 2 & Rimbo Bujang & 10 & $1,25 \pm 0,34$ \\
\hline 3 & Rimbo Ulu & 12 & $1,94 \pm 1,00$ \\
\hline \multicolumn{3}{|c|}{ Kabupaten Tebo } & $1,56 \pm 1,72$ \\
\hline
\end{tabular}

Sumber: Data diolah

Tabel 1 menunjukkan nilai S/C di Kecamatan Rimbo Ilir, Kecamatan Rimbo Bujang dan Kecamatan Rimbo Ulu program IB adalah $1,50 \pm 0,43 ; 1,25 \pm 0,34$; dan $1,94 \pm 1,00$. Nilai $\mathrm{S} / \mathrm{C}$ tersebut lebih baik dibandingkan pendapat Toelihere (1981) yang menyatakan bahwa kisaran untuk angka S/C normal untuk Indonesia adalah 1,60 -2,00. Dari ketiga kecamatan diatas Kecamatan Rimbo Bujang memiliki S/C yang lebih baik. Untuk melihat keberhasilan inseminasi buatan pada ternak dapat dilihat dari angka Service per Conception (S/C), artinya berapa kali inseminasi buatan harus dilakukan sampai ternak tersebut bunting. Nilai S/C menunjukkan tingkat kesuburan seekor ternak, jika nilai S/C nya rendah maka tingkat kesuburan ternak tersebut semangkin tinggi. Pada Kabupaten Tebo nilai S/C mennjukkan angka 1,56 $\pm 1,77$ yang kurang dari kisaran 1,60 - 2,00 berarti keberhasilan IB di Kabupaten Tebo yaitu baik. Angka S/C jika berada pada angka di bawah 2,00 yang berarti sapi masih dapat beranak 1 tahun sekali, apabila angka S/C di atas 2,00 akan menyebabkan tidak tercapainya jarak beranak yang ideal dan menunjukkan reproduksi sapi tersebut kurang efisien yang membuat jarak beranak menjadi lama, sehingga dapat merugikan peternak karena harus mengeluarkan biaya IB lagi. Sulaksono et. al. (2010) menyatakan bahwa tinggi rendahnya nilai S/C dapat dipengaruhi oleh beberapa faktor antara lain keterampilan inseminator, waktu dalam melakukan inseminasi buatan dan pengetahuan peternak dalam mendeteksi birahi. Angka S/C jika berada pada angka di bawah 2 yang berarti sapi masih dapat beternak 1 tahun sekali, apabila angka S/C di atas 2 akan menyebabkan tidak tercapainya jarak beranak yang ideal dan menunjukkan reproduksi sapi tersebut kurang efisien yang membuat jarak beranak menjadi lama, sehingga dapat merugikan peternak karena harus mengeluarkan biaya IB lagi. Penyebab tingginya angka S/C umumnya dikarenakan antara lain: peternak terlambat mendeteksi saat birahi atau terlambat melaporkan birahi sapinya kepada inseminator, adanya kelainan pada alat reproduksi induk sapi, inseminator kurang terampil, fasilitas pelayanan inseminasi yang terbatas, kurang lancarnya transportasi (Iswayono dan Widiyaningrum, 2008). Uji t-test independent pada Keberhasilan IB yang berupa S/C yang dilakukan bahwa dari ke 3 Kecamatan di Kabupaten Tebo menyatakan bahwa tidak terdapat perbedaan yang signifikan diantara setiap kecamatan di Kabupaten Tebo.

\section{Calving Interval $(\mathrm{CI})$}

Tabel 2. Calving Interval (CI)

\begin{tabular}{clcc}
\hline No & Kecamatan & N & Calving Interval (CI)/ (Bulan) \\
\hline 1 & Rimbo Ilir & 12 & $13,2 \pm 1,12$ \\
2 & Rimbo Bujang & 10 & $12,4 \pm 0,52$ \\
3 & Rimbo Ulu & 12 & $13,1 \pm 1,32$ \\
\hline Kabupaten Tebo & & $12,9 \pm 0,99$ \\
\hline
\end{tabular}

Sumber: Data diolah

Data calving interval (CI) di Kabupaten Tebo terlihat pada Tabel 2, dimana menunjukkan nilai Calving Interval (CI) pada ternak sapi di Kabupaten Tebo yaitu 12,9 bulan. Nilai CI yang paling rendah terdapat di Kecamatan Rimbo Bujang dengan nilai 12,4 $\pm 0,52$ bulan sedangkan nilai CI yang tertinggi terdapat di kecamatan Rimbo Ulu dengan nilai 13,1 $\pm 1,32$ bulan. Jarak beranak yang ideal adalah 12 bulan (Bozwort dkk, 1971), atau antara 12-14 bulan (Jainudeen dan Hafez, 1987).Dalam hal ini CI di Kabupaten Tebo sudah ideal sesuai dengan literatur yang menyatakan CI yang ideal antar 12-14 bulan. Uji t-test independent pada Keberhasilan IB yang berupa CI yang dilakukan bahwa dari ke 3 kecamatan di Kabupaten Tebo.

\section{Motilitas Spermatozoa}

Motilitas spermatozoa sangat diperlukan spermatozoa untuk mencapai ovum, membran telur dan melakukan penetrasi dalam fertilisasi. Motilitas sperma mempunyai korelasi yang tinggi dengan tingkat fertilitas 
Fachroerrozi Hoesni et al., Analisis Resistensi Spermatozoa Sapi Bali Terhadap Keberhasilan Inseminasi Buatan di Kabupaten Tebo

dan sangat penting artinya pada saat pembuahan (Toelihere, 1993).

Tabel 3. Motilitas Spermatozoa

\begin{tabular}{cccc}
\hline No & Kecamatan & Jumlah Straw & Motilitas $(\%)$ \\
\hline 1 & Rimbo Ilir & 12 & $37,10 \pm 5,10$ \\
2 & Rimbo Bujang & 10 & $36,95 \pm 2,05$ \\
3 & Rimbo Ulu & 12 & $38,72 \pm 4,02$ \\
\hline Kabupaten Tebo 34 & & $37,63 \pm 3,99$ \\
\hline
\end{tabular}

Sumber: Data yang diolah

Dari tabel 3 dapat dilihat bahwa nilai motilitas spermatozoa memiliki jumlah paling banyak yaitu $38,72 \%$ terdapat di kecamatan rimbo ulu dan $37,10 \%$ di kecamatan Rimbo Ilir, 36,95\% di kecamatan Rimbo Bujang. Kondisi ini diduga karena kerusakan pada straw yang berupa perenggangan pada filling-sealing sehingga nitrogen cair merembes dan masuk ke dalam straw dan mengakibatkan spermatozoa mati.

Persentase Hidup Spermatozoa

Tabel 4. Persentase Hidup Spermatozoa

\begin{tabular}{cccc}
\hline No & Kecamatan & Jumlah Straw & Persentase Hidup (\%) \\
\hline 1 & Rimbo Ilir & 12 & $43,90 \pm 8,99$ \\
2 & Rimbo Bujang & 10 & $37,48 \pm 4,00$ \\
3 & Rimbo Ulu & 12 & $41,43 \pm 7,00$ \\
\hline Kabupaten Tebo 34 & & $41,15 \pm 6,68$ \\
\hline
\end{tabular}

Sumber: Data diolah

Tabel 4 dapat dilihat Persentase Hidup Spermatozoa di lokasi penelitian di Kabupaten Tebo yaitu 41,15 $\pm 6,68$, yang artinya straw tersebut masih layak di gunakan, karena persentase spermatozoa hidup dalam kisaran normal.

\section{Abnormalitas Spermatozoa}

Abnormalitas yang teramati dari penelitian ini adalah abnormalitas sekunder yang dapat dilihat bagian ekor spermatozoa terputus, melingkar atau membengkok.

Tabel 5. Abnormalitas Spermatozoa

\begin{tabular}{clcc}
\hline No & Kecamatan & Jumlah Straw & Abnormalitas (\%) \\
\hline 1 & Rimbo Ilir & 12 & $12,09 \pm 1,77$ \\
2 & Rimbo Bujang & 10 & $13,18 \pm 0,61$ \\
3 & Rimbo Ulu & 12 & $12,30 \pm 1,43$ \\
\hline
\end{tabular}

Kabupaten Tebo 34 $12,47 \pm 1,44$

Sumber: Data diolah

Tabel 5 dapat dilihat Abnormalitas Spermatozoa di lokasi penelitian di kabupaten Tebo yaitu $12,47 \% \pm$ 1,44 , Menurut Toelihere (1993) bahwa selama abnormalitas spermatozoa belum mencapai $20 \%$ dari , maka semen tersebut masih dapat digunakan untuk inseminasi. Keadaan tersebut menunjukkan bahwa abnormalitas spermatozoa masih layak digunakan.
Pengaruh Motilitas, Persentase Hidup dan Abnormalitas Spermatozoa Terhadap Keberhasilan Inseminasi Buatan

Tabel 6. Hasil Analisis Regresi Linier Berganda

\begin{tabular}{lcccc}
\hline \multicolumn{1}{c}{ Variabel Bebas } & Variabel Terikat & Koefisien Regresi (B) & t Hitung & Sig \\
\hline & Keberhasilan IB (Y) & 0 & 704 & 0.643 \\
Motilitas (X1) & & 0.594 & 3.265 & 0.003 \\
Persentase Hidup (X2) & -0.181 & -900 & 0.375 \\
Abnormalitas(X3) & $\mathrm{r}=0.531$ & -0.088 & -507 & 0.616 \\
\hline \multicolumn{2}{c}{ r } & $\mathrm{R}=0.282$ & $\mathrm{Sig}=0.018$ \\
\hline
\end{tabular}

Sumber: Data diolah

Koefisien determinasi pada intinya mengukur seberapa jauh kemampuan model dalam menerangkan variasi variabel dependen. Nilai koefisien determinasi adalah antara nol dan satu. Nilai $\mathrm{R}^{2}$ yang kecil berarti kemampuan variabel-variabel independen dalam menjelaskan variasi variabel dependen amat terbatas. Dalam Tabel 6 menunjukkan nilai R-Square yang sebesar 0,282 yang berarti bahwa proporsi pengaruh variabel motilitas, persentase hidup, abnormalitas spermatozoa memiliki pengaruh terhadap keberhasilan inseminasi buatan sebersar 28,2\%. Ini berarti bahwa motilitas, persentase hidup, abnormalitas Spermatozoa memiliki pengaruh terhadap keberhasilan inseminasi buatan pada sapi di Kabupaten Tebo sebesar 28,2\% sedangkan sisanya $71,8 \%$ dipengaruhi variabel lain yang tidak ada dalam model regresi linier. Uji statistik $F$ pada dasarnya menunjukkan apakah semua variabel independen yang dimasukkan dalam model mempunyai pengaruh secara bersama-sama terhadap variabel terikat (Ghozali, 2013). Berdasarkan Tabel 12 uji F menunjukkan bahwa nilai $F_{\text {hitung }}$ diperoleh sebesar 3.929 dengan tingkat $\mathrm{Sig} 0,018^{\mathrm{b}}$ atau memperoleh nilai signifikasi 0,018 lebih kecil dari nilai probabilitas 0,05. Hal ini berarti secara bersama-sama variabel Motilitas $\left(\mathrm{X}_{1}\right)$, Persentase Hidup $\left(\mathrm{X}_{2}\right)$, dan Abnormalitas (X3) berpengaruh secara signifikasi terhadap tingkat keberhasilan inseminasi buatan pada sapi (Y) di Kabupaten Tebo. Uji statistik $t$ pada dasarnya menunjukkan seberapa jauh pengaruh satu variabel independen $(\mathrm{X})$ secara individual dalam menerangkan variabel dependen (Y). Pengujian dilakukan dengan menggunakan signifikan level 0,05 ( $\alpha=5 \%)$ (Ghozali, 2013).

Pengaruh motilitas, persentase hidup, dan abnormalitas spermatozoa terhadap keberhasilan inseminasi buatan pada sapi di Kabupaten Tebo Motilitas Spermatozoa

Variabel Motilitas $\left(\mathrm{X}_{1}\right)$ pada persamaan keberhasilan inseminasi buatan $(\mathrm{Y})$ menghasilkan nilai $t_{\text {statistik }}$ sebesar 3,265 dengan tingkat Prob. $t_{\text {statistik }}$ sebesar 0,003 yang mempunyai arti signifikan. Hasil estimasi ini menjelaskan bahwa Motilitas $\left(\mathrm{X}_{1}\right)$ berpengaruh terhadap keberhasilan inseminasi buatan (Y). Perubahan (kenaikan atau penurunan) $\mathrm{X}_{1}$ menyebabkan (kenaikan atau penurunan) terhadap keberhasilan Inseminasi Buatan (Y). 


\section{Persentase Hidup Spermatozoa}

Variabel Persentase Hidup $\left(\mathrm{X}_{2}\right)$ pada persamaan keberhasillan inseminasi buatan (Y) dihasilkan nilai $\mathrm{t}_{\text {statistik }}$ sebesar -900 dengan tingkat Prob.(t-statistik) sebesar 0,375 yang mempunyai arti tidak signifikan. Hasil estimasi ini menjelaskan bahwa persentase hidup $\left(\mathrm{X}_{2}\right)$ tidak berpengaruh terhadap keberhasilan Inseminasi Buatan (Y). Perubahan (kenaikan atau penurunan) $\mathrm{X}_{2}$ tidak menyebabkan perubahan (kenaikan atau penurunan) keberhasilan Inseminasi Buatan (Y).

\section{Abnormalitas Spermatozoa}

Variabel Abnormalitas $\left(\mathrm{X}_{3}\right)$ pada persamaan keberhasilan inseminasi buatan (Y) dihasilkan nilai $\mathrm{t}_{\text {statistik }}$ sebesar -507 dengan tingkat Prob.(t-statistik) sebesar 0,616 yang mempunyai arti tidak signifikan. Hasil estimasi ini menjelaskan bahwa abnormalitas $\left(\mathrm{X}_{3}\right)$ tidak berpengaruh terhadap keberhasilan inseminasi buatan (Y). Perubahan- Perubahan (kenaikan atau penurunan) abnormalitas $\left(\mathrm{X}_{3}\right)$ tidak menyebabkan perubahan (kenaikan atau penurunan) keberhasilan Insemnasi Buatan (Y).

\section{SIMPULAN}

1. Keberhasilan Inseminasi Buatan (IB) di Kabupaten Tebo dikatakan baik.

2. Motilitas mempengaruhi keberhasilan Inseminasi Buatan (IB), sedangkan Persentase Hidup dan Abnormalitas Spermatozoa tidak berpengaruh terhadap keberhasilan Inseminasi Buatan pada sapi.

\section{DAFTAR PUSTAKA}

Badan Pusat Statistik. 2010. Analisis dan Penghitungan Tingkat Kemiskinan. Jakarta

Frandson .R.D. 1993 . Darah dan cairan tubuh lainnya. edisi ke 4 Gajah Mada University Press

Ghozali, I. 2013. Aplikasi Analisis Multivariate dengan Program IBM SPSS 21. Badan Penerbit Universitas Diponegoro. Semarang.

Hafez, E.S.E. 1993. Artificial Insemination. In: Reproduction in Farm Animlas:6th Ed. Lea and Febiger, Philadelphia,pp.424-439.

Hunter, R.H.F. 1992. Fisiologi Dan Teknologi Reproduksi Hewan Betina Domestik. Skripsi. Institut Teknologi Bandung, Bandung.

Iswayono, dan P. Widiyaningrum. 2008. Performans reproduksi sapi peranakan simmental (psm) hasil inseminasi buatan di kabupaten sukoharjo jawa tengah. Jurnal Ilmiah Ilmu-ilmu Peternakan. 9 (3) : 125-133.

Jainudeen, H.R. and E.E. Hafez. 1987. Gestation, Prenatal Physiology And Parturition, In Reproduction In Farm Animals. Sed. Ed. Lea And Febiger. Philadelphia.

Kutner, M.H., C.K. Nachtsheim Dan J. Neter. 2004. Applied Linear Regression Models. Fourth Ed. The McGraw Hill Company, Inc. New York.
Singarimbun, M. dan S. Effendi. 1984. Metode Penelitian Survei. PT. Pustaka Lembaga Penelitian, Pendidikan Dan Penerangan Ekonomi dan Sosial. Jakarta.

Sugiyono. 2011. Metode Penelitian Kuantitatif Kualitatif Dan R\&D. Alfabeta. Bandung.

Sulaksono, A., S. Suharyati, dan E.P. Santoso. 2010. Penampilan Reproduksi (Servise Per Conception, Lama Bunting Dan Selang Beranak) Kambing Boerawa Di Kecamatan Gedong Tataan Dan Kecamatan Gisting. Skripsi. Fakultas Pertanian. Universitas Lampung, Lampung.

Tan, P.N., M. Steinbach,and V. Kumar. 2006. Introduction To Data Mining. Pearson Education. Boscom.

Toelihere, M.R. 1981. Fisiologi Reproduksi Ternak. Angkasa. Bandung.

Toelihere, M.R. 1993. Inseminasi Buatan Pada Ternak. Angkasa. Bandung. 